\title{
ACTIVE SHARING KNOWLEDGE UNTUK MENINGKATKAN KUALITAS PEMBELAJARAN GURU- GURU MATEMATIKA SMA/SMK BINAAN MELALUI PENDAMPINGAN DI KULON PROGO
}

\author{
Giyarsih \\ Pengawas Dinas Pendidikan \\ email: asih125@yahoo.co.id
}

\begin{abstract}
This research is meant to explain the problem solving efford which is found in academic supervision toward teachers of Mathematics in some guided schools, explains the problem solving steps by the supervisor in guided schools, and shows the teaching quality improvement by the Mathematics teachers in those guded schools. This research was done to some guded schools where ten Mathematics teachers of Senior High Schools or Vocational High School in Kulon Progo District are the subject. The strategy for improving the quality of Mathematics teaching application is through treatment of companion teaching in active sharing knowledge for instance through planning, the step of treatment in the teaching, teaching procedures and class management. The result of acompaniying the teachers of Mathematics shows that Mathematics teachers in Kulon Progo Distric still need some guidance from the supervisors especially in term of innovative teaching process, where most teachers lack of motivation, the Active Sharing Knowledge method can improve the activism of the teachers through out the whole teaching activities, improve the quality of teaching process, students' activism, concept mastery and teacher's skills in teaching process as can be seen as followed: the teaching quality of Mathematics teachers using Active Sharing Knowledge is 5\%, student's participations is 46\%, while teachers' mastery of the concept is $14 \%$, and positive reflection as a result of Mathematics Teachers guided teaching implementation using Active Sharing Knowledge where $84 \%$ stated agree and totally agree.
\end{abstract}

Key Words: Active Sharing Knowledge, Improvement of Teaching Quality and Guidance.

Abstrak: Tujuan Penelitian ini adalah menjelaskan upaya pemecahan masalah yang ditemukan dalam supervisi akademik terhadap guru-guru Matematika disekolah binaan, menjelaskan langkah-langkah pemecahan masalah yang ditempuh pengawas disekolah binaan, dan menunjukkan peningkatan kualitas pembelajaran guru-guru Matematika di sekolah Binaan. Penelitian ini dilaksanakan pada sekolah binaan dengan objek Guru-Guru Matematika SMA/SMK di Kabupaten Kulon Progo sejumlah sepuluh orang guru Matematika. Strategi peningkatan kualitas pelaksanaan pembelajaran Matematika adalah melalui treathment pendampingan pembelajaran Active Sharing Knowledge antara lain tahap perencanaan, tahap treatmen pembelajaran Active Sharing Knowledge, prosedur pembelajaran Active Sharing Knowledge, dan pengelolaan kelas. Hasil pendampingan terhadap sepuluh orang guru matematika binaan, penulis menyimpulkan bahwa Guru-guru matematika di Kabupaten Kulon Progo ternyata masih sangat memerlukan pendampingan dari pengawas khususnya mengenai pelaksanaan proses pembelajaran inovatif, masih perlu adanya motivasi pengawas terhadap guru matematika, metode Active Sharing Knowledge dapat mengoptimalkan keaktifan guru dan siswa dari awal hingga akhir pembelajaran, meningkatkan kualitas proses pembelajaran, aktivitas siswa, penguasaan konsep, dan keterampilan guru dalam proses pembelajaran. Adapun besaran peningkatan tersebut sebagai berikut ini. Kualitas pembelajaran guru-guru Matematika dengan Active Sharing Knowledge sebesar 5\%. Besarnya peningkatan keaktifan siswa mencapai 46\%, sedangkan peningkatan penguasaan konsep Matematika mencapai 14\%. Diperoleh refleksi positif dari hasil pendampingan pelaksanaan pembelajaran guru-guru Matematika dengan Active Sharing Knowledge sebesar $84 \%$ menyatakan setuju dan sangat setuju.

Kata Kunci: Active Sharing Knowledge, Peningkatan Kualitas Pembelajaran, Pendampingan 


\section{PENDAHULUAN}

Sesuai dengan tuntutan dalam kurikulum 2013 proses pembelajaran di kelas diharapkan mampu mengembangkan tiga kompetensi siswa, yaitu kompetensi kognitif, psikomotorik, dan afektif. Dengan demikian model pembelajaran di kelas hendaknya benar-benar mengacu ke arah terwujudnya ketiga kompetensi tersebut diatas. Untuk itu guru harus mampu memahami kurikulum yang berlaku, mampu memilih metode pem-belajaran yang tepat, memilih dan meng-gunakan media pembelajaran sesuai dengan materi yang disampaikan.

Pembelajaran di lingkungan sekolah harus didesain untuk menjadikan pembelajaran yang mandiri dan menggunakan pendekatan ilmiah. Kesalahan konsep, harus dihindari melalui perencanaan pembelajaran, sehingga hasil akhir pembelajaran sesuai dengan tujuan pembelajaran itu sendiri yang dapat menghantarkan siswa meraih hasil pembelajaran optimal. Untuk memenuhi tuntutan pembelajaran matematika yang berkualitas dapat dilakukan dengan menggunakan media pembelajaran yang sesuai, karena media pembelajaran merupakan sarana untuk mengembangkan pemahaman konsep matematika yang lebih bermakna.

Dari hasil supervisi akademik satu tahun terakhir yang dilakukan pengawas ditemukan bahwa pelaksanaan pembelajaran guru-guru matematika masih konvensional, aktivitas pembelajaran didalam kelas masih didominasi oleh guru sehingga aktivitas siswa belum optimal. Kondisi tersebut jika dibiarkan akan berdampak pada ketidaktercapaian ketiga aspek kompetensi yang seharusnya dikuasai oleh siswa. Akibatnya perolehan hasil belajar siswa tidak seperti yang diharapkan.
Berdasarkan permasalahan tersebut penulis memandang perlu mengenalkan model pembelajaran yang benar-benar mampu mengoptimalkan aktivitas siswa selama proses belajar berlangsung serta mampu mewujudkan perolehan hasil belajar siswa secara utuh berupa penguasaan kognitif, psikomotorik, dan afektif. Sehubungan dengan itu, penulis memandang perlu mengenalkan model pembelajaran Active Sharing Knowledge melalui pendampingan agar guru dapat menginovasi proses pembelajaran sebagai solusi untuk mengatasi semua permasalahan di atas.

Sebenarnya ada berbagai cara untuk mengatasi kebiasaan guru yang dalam proses pembelajaran mereka masih konvensional. Misalnya dengan kunjungan kelas oleh pe-ngawas terhadap guru-guru binaan. Kunjungan kelas yang dilakukan oleh pengawas ketika guru menyampaikan proses pembelajaran, pengawas mengamati dan memberikan saran dan penilaian setelah pembelajaran berakhir. Akan tetapi hal ini sangat tidak efektif karena memerlukan banyak waktu dan pengawas berubah fungsi sebagai nara sumber yang serba tahu. Cara lain adalah teknik workshop para guru dikumpulkan diberi berbagai teori dan informasi untuk diterapkan dalam pembelajaran di kelas. Akan tetapi hal ini akan memerlukan banyak dana, domisili terpisah-pisah, dan kemampuan guru untuk menyerap informasi berbeda-beda. Sehingga hasil pembinaan dengan cara ini hasilnya tidak dapat dipertanggungjawabkan. Mengingat kenyataan tersebut penulis berusaha mengatasi permasalahan di atas berupa pendampingan berkelanjutan untuk memotivasi para guru matematika menggunakan pembelajaran Active Sharing Knowledge.

Penelitian ini ditulis dengan tujuan sebagai berikut ini: 1) menjelaskan upaya pemecahan masalah yang ditemukan dalam 
supervisi akademik terhadap guru-guru matematika di sekolah binaan, 2) menjelaskan langkah-langkah pemecahan masalah yang digunakan pengawas pada pembinaan tentang pelaksanakan model pembelajaran Active Sharing Knowledge di sekolah binaan, 3) menunjukkan peningkatan kualitas pembelajaran guru-guru matematika dengan Active Sharing Knowledge disekolah binaan, 4) menunjukkan peningkatan hasil belajar matematika dengan Active Sharing Knowledge bagi siswa di sekolah binaan

\section{METODE}

Penelitian ini merupakan penelitian tindakan sekolah dengan pendampingan. Tindakan pendampingan ini dilakukan dengan pendampingan berkelanjutan mulai tahap perencanaan, pelaksanaan, pengamatan dan refleksi.

Sebagai upaya pemecahan yang dihadapi di lapangan penulis mengadakan pendampingan secara berkelanjutan terhadap sejumlah guru matematika di SMA/ SMK binaan untuk menerapkan model pembelajaran Avtive Sharing Knowledge di sekolah masing-masing. Pendampingan tersebut dilaksanakan di SMA Muhammadiyah Wates, SMK Ma'arif 1 Wates, dan SMK Ma'arif 3 Wates selama satu tahun pelajaran 2013/2014.

Pendampingan adalah pemberian bantuan kepada perorangan ataupun kelompok untuk menumbuhkan kesadaran dalam rangka pemenuhan kebutuhan dan penyelesaian permasalahan yang dihadapi (Muzaqi, 2004). Dalam konteks ini yang dimaksud pendampingan adalah pemberian bantuan kepada guru-guru matematika dalam rangka mengatasi permasalahan umum yang mereka hadapi dalam proses pebelajaran matematika di kelas, yakni mulai dari tahap identifikasi masalah, mencari alternatif pemecahan masalah sampai dengan implementasinya.

Tujuan pendampingan adalah mengenalkan metode pembelajaran Avtive Sharing Knowledge kepada para guru binaan sebagai alternatif pemecahan masalah di lapangan.

Treatmen pendampingan ini dilakukan dengan pendampingan berkelanjutan mulai tahap perencanaan, pelaksanaan, pengamatan dan refleksi dengan langkah-langkahnya seperti diuraikan dibawah:

\section{Tahap Perencanaan}

Pada tahap ini yang dipersiapkan: a) mengumpulkan guru-guru matematika binaan di setiap sekolah binaan oleh pengawas sekolah; b) Melakukan sosialisasi kepada guru-guru matematika tentang Active Sharing Knowledge; c) Menyusun komitmen bersama; d) menentukan waktu pelaksanaan pembimbingan tentang Active Sharing Knowledge disekolah masing-masing guru.

\section{Tahap Pelaksanaan}

Guru-guru matematika dibimbing pengawas tahapan-tahapan yang harus dilakukan dalam melakukan pembelajaran Active Sharing Knowledge diantaranya: 1) Tahap awal: (a) menjelaskan pembelajaran menggunakan Active Sharing Knowledge; (b) menjelaskan langkah-langkah yang dilakukan dalam pembelajaran menggunakan Active Sharing Knowledge; 2) Tahap pendampingan perencanaan pembelajaran, meliputi: (a) pemetaan materi pembelajaran dari SKL, KI, dan KD, (b) Pengembangan Silabus, (c) Perencanaan pelaksanaan pembelajaran (RPP), (d) Lembar Kerja Siswa, (e) Lembar pengamatan kegiatan siswa dalam pembelajaran.

\section{Tahap Pengamatan Pelaksanaan Pembe- lajaran}


Pada tahapan ini pengawas mengamati pelaksanaan pembelajaran tentang bagaimana guru binaan melaksanakan pembelajaran model Active Sharing Knowledge menggunakan instrument pengamatan. Waktu pengamatan dikoordinasikan dulu dengan guru binaan.

\section{Tahap Refleksi}

Setelah akhir pembelajaran pengawas melakukan diskusi tentang catatan-catatan kegiatan pembelajaran yang dilakukan oleh guru. Guru diberi kesempatan untuk menemukan sendiri kekurangannya, kemudian pengawas membantu mencari solusinya, jika diperlukan bisa melakukan pemodelan.

Pelaksanaan Proses pembelajaran Active Sharing Knowledge sesuai dengan perencanaan dan menggunakan lembar pengamatan keaktifan siswa, diantaranya meliputi:

\section{Pra pelaksanaan pembelajaran}

Kegiatan yang dilakukan antara lain: a) mempersiapkan media pembelajaran berbasis ICT atau cetak, b) membagikan Lembar Kerja Siswa

\section{Pelaksanaan pembelajaran Active Sharing Knowledge}

Kegiatan yang dilakukan antara lain: 1) Memastikan bahwa prasyarat pembelajaran sudah terpenuhi; 2) Mengkondisikan siswa untuk masuk dalam pembelajaran; 3) Mengawali proses pembelajaran, antara lain dengan cara: (a) menyiapkan peserta didik secara psikis dan fisik untuk mengikuti proses pembelajaran, (b) mengajukan pertanyaan yang mengaitkan pengetahuan sebelumnya dengan materi yang akan dipelajari, (c) menjelaskan tujuan pembelajaran/kompetensi dasar yang dicapai, (d) menyampaikan cakupan materi dan pen- jelasan kegiatan pembelajaran sesuai silabus, (e) menyampaikan rencana kegiatan yaitu kerja kelompok; 4) Melaksanakan kegiatan eksplorasi: (a) melibatkan peserta didik mencari informasi yang luas dan dalam tentang topik materi yang akan dipelajari dengan menerapkan prinsip dan sumber belajar lainnya, (b) menggunakan beragam pendekatan, media pembelajaran yang sesuai dengan materi dan sumber belajar lain yang sesuai dengan materi ajar yang disampaikan, (c) memfasilitasi terjadinya interaksi peserta dan guru dan antara peserta didik dan peserta didik, lingkungan dan sumber belajar melalui diskusi, penelusuran informasi, dan pengamatan pada media pembelajaran, (d) melibatkan peserta didik secara aktif dalam setiap kegiatan pembelajaran, 5) Melaksanakan kegiatan eksplanasi, antara lain dengan cara: (a) membiasakan peserta didik membaca dan menulis yang beragam melalui tugas-tugas atau menggunakan lembar kerja siswa, (b) guru menyampaikan bahan ajar secara singkat (tahap orientasi masalah), (c) guru membagi siswa dalam kelompok (tahap mengorganisasikan siswa), (d) memberi berbagai macam aktivitas untuk mendapatkan konsep yang representative, (e) memfasilitasi pelaksanaan diskusi untuk memahami bahan ajar, belajar dalam kelompok, dan mengerjakan tugas-tugas, (f) memfasilitasi peserta didik untuk mencari tahu, mencoba, mengamati, menganalisis, menalar, berfikir logis, sistematis secara berkelompok; 6) Melaksanakan kegiatan ekspansi, antara lain dengan cara: a) guru menugaskan siswa mengembangkan konsep selanjutnya. Siswa menyusun rancangan pengembangan konsep, b) memberikan tugas agar berdiskusi untuk memunculkan gagasan baru secara lisan maupun tertulis; 7) Tahap Evaluasi: (a) guru menilai karya siswa dan penyajiannya dalam forum diskusi dengan cara 
mengisi instrumen lembar observasi untuk mengumpulkan dan menganalisis data tentang pengetahun yang dikuasai siswa, sikap yang ditunjukkan serta keaktifan aktivitas siswa selama proses pembelajaran, (b) Salah satu siswa dari salah satu kelompok merefleksi dan menyajikan hasil diskusi dalam mengerjakan soal, (c) guru memberi kesempatan kepada kelompok lain untuk menanggapi hasil diskusi, (d) guru memberi konfirmasi, (e) siswa diberi kesempatan untuk melakukan refleksi terhadap pengalaman belajar yang sudah dilakukan.

\section{Pengelolaan Kelas}

Pada tahapan ini kegiatan yang dilakukan diantaranya: 1) mengatur tempat duduk sesuai dengan karakteristik peserta didik dan mata pelajaran, serta aktivitas pembelajaran dalam RPP; 2) memastikan volume dan intonasi suara guru dalam proses pembelajaran dapat didengar dengan baik oleh seluruh peserta didik; 3) menggunakan tutur kata santun, dapat dimengerti oleh peserta didik; 4) menyesuaikan materi pelajaran yang disampaikan dengan kecepatan dan kemampuan peserta didik; 5) menciptakan ketertiban, kedisiplinan, kenyamanan, keselamatan, dan kepatuhan pada peraturan penyelenggaraan proses pembelajaran; 6) memberikan penguatan dan umpan balik terhadap respons dan hasil belajar peserta didik selama proses pembelajaran berlangsung; 7) hargai seluruh peserta didik tanpa memandang latar belakang agama, suku, jenis kelamin, dan status sosial; 8) menghargai dan memberi tanggapan pendapat peserta didik; 9) mengenakan pakaian yang sopan, bersih, dan rapi; 10) berpenampilan menarik; 11) menyampaikan silabus mata pelajaran pada setiap awal semester; 12) memulai dan mengakhiri proses pembelajaran sesuai dengan waktu yang dijadwalkan.

\section{Tahap observasi/ pengamatan}

Pada tahap ini, peneliti melakukan pengamatan dengan menggunakan lembar pengamatan kepada guru-guru matematika yang menjadi sasaran penerapan pembelajaran dengan Active Sharing Knowledge di sekolah binaan antara lain adalah: 1) melakukan diskusi sebelum masuk kelas; 2) melakukan pengamatan proses pembelajaran; 3) mencermati langkah-langkah guru dalam melakukan pembelajaran dengan Active Sharing Knowledge; 4) melakukan diskusi setelah kegiatan pembelajaran; 5) memberi kesempatan guru menyampaikan permasalahan di kelas; 6) memberi kesempatan guru untuk menemukan sendiri kelebihan dan kekurangannya; 7) membantu mencari solusi dari permasalahan yang dihadapi guru.

Teknik pengumpulan data dalam penelitian tindakan sekolah ini menggunakan angket, observasi, dan dokumen.

Data kuantitatif dianalisa secara deskriptif dengan menggunakan tabel, mean dan prosentase bahkan jika dimungkinkan bisa menggunakan grafik. Sedangkan untuk data kualitatif dari hasil pengamatan peneliti bersama peserta pembinaan dan pendampingan, dianalisis dengan menggunakan metode analisis kualitatif. yaitu dengan mengadakan wawancara atau memadukan hasil pengamatan antara peneliti dengan peserta pembinaan dan pendampingan.

\section{HASIL DAN PEMBAHASAN}

Penulis melakukan supervisi awal kepada seluruh responden dalam proses pembelajaran sebelum dikenalkan model pembelajaran Active Sharing Knowledge melalui pendampingan. Hasilnya menunjukkan bahwa penguasaan konsep matematika oleh siswa rata-rata sebesar 51,5\% menunjukan hasil pembelajaran cukup dan $34,5 \%$ menunjukan hasil pembelajaran 
baik. Sedangkan untuk keaktifan siswa yang aktif $27,5 \%$ dan yang kreatif $62,5 \%$.

Setelah dilakukan pendampingan diperoleh hasil penilaian pelaksanaan pembelajaran dengan Active Sharing Knowledge menunjukan hasil pembelajaran penguasaan konsep matematika cukup sebesar $8 \%$ yang baik $61 \%$ dan yang sangat baik $32 \%$. Sedangkan untuk keaktifan siswa yang aktif $58 \%$ sangat aktif $37 \%$ dan yang kreatif $5 \%$.

Berdasarkan pengamatan pelaksanaan pembelajaran Active Sharing Knowledge yang dilakukan oleh guru-guru matematika SMA/SMK di sekolah binaan setelah diberi treatmen melalui pendampingan, ternyata ada empat orang guru yang melaksanakan pembelajaran Active Sharing Knowledge menggunakan media pembelajaran berbasis $I C T$, yang enam orang guru menggunakan media cetak.

Hasil penilaian refleksi siswa terhadap proses pembelajaran guru-guru matematika dengan Active Sharing Knowledge yang diperoleh dengan instrumen angket untuk menjaring data tentang refleksi siswa terhadap proses pembelajaran, yang meliputi beberapa aspek (senang belajar, mudah memahami bahan pelajaran, termotivasi untuk belajar, meningkatkan kemampuan berpikir kritis, dan berani menyampaikan pendapat), menunjukkan bahwa rata-rata: 1) banyaknya siswa yang senang belajar matematika se-besar $88 \%$; 2) banyaknya siswa yang mudah memahami bahan pelajaran sebesar $90 \%, 3)$ banyaknya siswa yang termotivasi untuk belajar 94\%, 4) banyaknya siswa yang meningkatkan kemampuan berpikir kritis sebesar 90\%, 5) berani menyampaikan pendapat sebesar $96 \%$.

\section{DAFTAR PUSTAKA}

Abdul Azis Wahab (2004) Metode dan Model-model Mengajar Ilmu Penge-
Bertolak dari hasil pendampingan ini tentunya sangat perlu akan adanya pengem-bangan ke depan sehingga sangat bermanfaat di dalam pembelajaran matematika pada khususnya dan mata pelajaran lain pada umumnya.

Akan tetapi, penulis menyadari benar bahwa dalam melaksanakan langkah tersebut pasti dijumpai beberapa hambatan yang sangat perlu untuk dipikirkan lebih lanjut. Diantaranya adalah masalah dana, sarana prasarana, minat dan kesungguhan para guru binaan. Oleh karena itu rencana pengembangan ini sangat membutuhkan keterlibatan berbagai pihak antara lain adalah Dinas Pendidikan Kabupaten Kulon Progo, dan sekolah-sekolah binaan.

\section{SIMPULAN}

Dari hasil pendampingan terhadap sepuluh orang guru matematika binaan tersebut penulis menyimpulkan sebagai berikut: 1) Guru-guru matematika di Kabupaten Kulon Progo ternyata masih sangat memerlukan pendampingan dari pengawas khususnya mengenai pelaksanaan proses pembelajaran inovatif; 2) Masih perlu adanya motivasi pengawas terhadap guru matematika; 3) Dari hasil pengamatan selama pendampingan ternyata metode Active Sharing Knowledge dapat mengoptimalkan keaktifan guru dan siswa dari awal hingga akhir pembelajaran; 4) Metode Active Sharing Knowledge ternyata dapat meningkatkan kualitas proses pembelajaran, aktivitas siswa, penguasaan konsep, dan keterampilan guru dalam proses pembelajaran.

tahuan Sosial Berkompetensi. Surabaya: JP Books 
Ariyati, 2006. Usaha meningkatkan berko-munikasi dan aktivitas siswa pada pembelajaran matematika bagi siswa SMP. Yogyakarta: Perdana.

Depdiknas, 2006. Pedoman Pelaksanaan Kurikulum. Jakarta: Balai Pustaka.

Giyarsih (2010). Upaya meningkatkan kemandirian, motivasi, aktivitas, dan prestasi belajar siswa SMA kelas XI - IPA - 1 tahun 2010/ 2011.

Nahadi, 2013. Peningkatan Kualitas Pembelajaran melalui Program LBS. FPMIPA UPI.

Purwanto, 2008. Meningkatkan Motivasi dan Aktivitas Belajar Mengarang Bahasa Indonesia Melalui Permainan Gambar Berseri di Kelas III SD Negeri Pengkol semester 2 Tahun Pelajaran 2008/2009. Yogyakarta: Perdana.
Sri Suharyanti, 2006. Upaya Peningkatan Prestasi Hasil Belajar Siswa Menggunakan Metode Kooperatif STAD. Yogyakarta: Perdana.

, 2013. Permendikbud no. 64 tentang SI. Jakarta: Lembaran Negara. , 2013. Permendikbud no.65 tentang standar proses. Jakarta: Lembaran Negara. , 2013. Permendikbud no.66 tentang standar penilaian. Jakarta: Lembaran Negara.

2013. Lampiran permendikbud no. 81A terus dilakukan selama pelaksanaan kurikulum 2013. Jakarta: Lembaran Negara. 